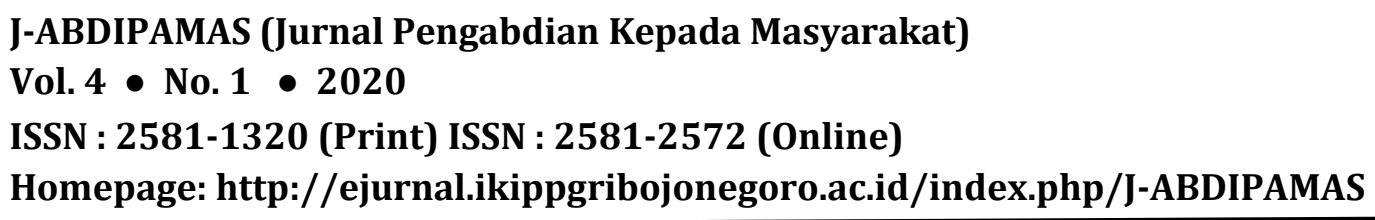

\title{
PELATIHAN IDENTIFIKASI BORAKS DAN FORMALIN PADA MAKANAN DI KELURAHAN TANJUNG AYUN SAKTI
}

\author{
Friska Septiani Silitonga ${ }^{1}$, Fitriah Khoirunnisa $^{2}$, Eka Putra Ramdhani $^{3}$ \\ ${ }^{1}$ Universitas Maritim Raja Ali Haji. Email: friska.septiani89@umrah.ac.id \\ 2Universitas Maritim Raja Ali Haji. Email: fitriahk@umrah.ac.id \\ 3 Universitas Maritim Raja Ali Haji. Email: ramdhani@umrah.ac.id
}

\begin{abstract}
Borax and formalin are wood preservatives, cleaning agents, antiseptics but are not intended for food. Based on data from ВРОМ, currently borax and formalin are used by some traders as food preservatives. The Problems faced by the community are: 1) there are food products that use borax and formaln, 2) people don't know how to identify preservatives contained in food, 3) people don't know the dangers of preservatives to health. The purpose of this activity are: 1) Giving education about the characteristics of foods containing borax and formalin, 2) training how to identify preservatives 'such as borax and formalin using simple methods; 3) determine the percentage of samples containing borax and formalin. The methods used in carrying out this activity are: 1) survey, 2) preparation, 3) socialization, 4) training, 5) evaluation. The results obtained are increased public understanding of the characteristics of foods that contained by borax and formalin, increased skills in identifying borax and formalin using numerical paper and hibiscus paper. From 15 samples tested, there were 2 samples (13.3\%) food contained by borax and 6 samples (40\%) containing formalin.
\end{abstract}

Keywords: Borax, formalin, food

\section{ABSTRAK}

Boraks dan formalin merupakan bahan pengawet kayu, bahan pembersih, antiseptik tetapi tidak diperuntukkan untuk makanan. Berdasarkan data dari BPOM, saat ini boraks dan formalin digunakan oleh sebagian pedagang sebagai bahan pengawet makanan. Permasalahan yang dihadapi masyarakat yaitu: 1) ada produk pangan yang menggunkan boraks dan formalin, 2) masyarakat belum mengetahui cara identifikasi bahan pengawet yang terdapat dalam makanan, 3) masyarakat belum mengetahui bahaya bahan pengawet terhadap kesehatan. Tujuan dari kegiatan ini yaitu:1) pemberian edukasi mengenai ciri-ciri makanan yang mengandung boraks dan formalin, 2) pelatihan mengidentifikasi bahan pengawet seperti boraks dan formalin dengan menggunakan simple methods; 3) mengetahui persentase sampel yang mengadung boraks dan formalin. Metode yang digunakan dalam pelaksanaan kegiatan ini yaitu: 1) survei, 2) persiapan, 3) sosialisasi, 4) pelatihan, 5) evaluasi. Hasil yang diperoleh yaitu meningkatnya pemahaman masyarakat mengenai ciri-ciri makanan yang mengandung boraks dan formalin, meningkatnya keterampilan mengidentifikasi boraks dan formalin dengan menggunakan kertas tumerik dan kertas bunga kembang sepatu. Dari 15 sampel yang di uji, terdapat 2 sampel (13,3\%) makanan mengandung boraks dan 6 sampel (40\%) mengandung formalin.

Kata Kunci: Boraks, formalin, makanan

\section{PENDAHULUAN}

Panganan hasil olahan laut yang sering diolah oleh masyarakat di kota Tanjungpinang, Kepulauan Riau, yaitu otak-otak. Otak-otak merupakan makanan berbahan dasar tepung dan bahan baku dari hasil laut, seperti sotong (cumi-cumi) atau ikan, yang dibentuk menjadi adonan bertekstur liat lalu dibungkus dengan daun kelapa kemudian dibakar. Selain otak-otak, juga terdapat bahan makanan seperti tahu, bakso, 
mi, dan pempek yang banyak di produksi di Provinsi Kepulauan Riau. Bahan makan ini merupakan bahan yang tidak dapat bertahan lama jika berinteraksi dengan udara, sehingga untuk meningkatkan daya tahan makanan terhadap mikroorganisme maka diperlukan bahan pengawet untuk mencegah terjadinya kerusakan pada makanan.

Menurut Peraturan Menteri Kesehatan RI Nomor 033 tahun 2012 pasal 1 ayat 1 menyatakan bahwa bahan tambahan pangan merupakan bahan yang ditambahkan kedalam pangan untuk mempengaruhi sifat atau bentuk pangan. Bahan tambahan pangan (BTP) secara umum merupakan bahan yang biasanya tidak digunakan sebagai bahan makanan, mempunyai atau tidak mempunyai nilai gizi, dan sengaja ditambahkan ke dalam makanan dengan tujuan teknologi pada proses pembuatan, pengolahan, penyiapan, perlakuan, pengepakan, pengemasan, serta penyimpanan(Cahyadi, W 2008). Adapun tujuan dari penggunaan BTP yaitu untuk mempertahankan atau meningkatkan nilai gizi dan kualitas daya simpan, membuat bahan pangan lebih mudah dihidangkan serta mempermudah dalam penyiapan bahan pangan. Salah satu contoh bahan tambahan pangan yang sering ditambahkan dalam pangan yaitu pengawet.

Bahan pengawet merupakan bahan yang digunakan untuk mempertahankan kualitas dan daya simpan pangan. Biasanya bahan pengawet ditambahkan untuk mengawetkan bahan pangan yang mempunyai sifat mudah rusak. Di satu sisi, penggunaan bahan pengawet memberikan keuntungan dikarenakan bahan pangan dapat bebas dari kehidupan mikroba, baik yang bersifat patogen yang dapat menyebabkan keracunan atau gangguan kesehatan lainnya maupun mikrobial yang nonpatogen yang dapat menyebabkan kerusakan bahan pangan seperti pembusukan. Permasalahan yang dapat ditimbulkan dari penggunaan bahan pengawet yaitu dalam proses metabolisme, konsumsi bahan pengawet yang berlebihan akan menyebabkan terjadinya terjadi penumpukan bahan pengawet di dalam tubuh sehingga dampak yang ditimbulkan tidak langsung terjadi dan dapat mengakibatkan gangguan di beberapa organ tubuh.

Berdasarkan Peraturan Menteri Kesehatan Nomor 033/2012, bahan pengawet yang dilarang penggunaannya sebagai BTP yaitu seperti asam borat dan senyawanya (boraks), serta formalin. Boraks termasuk bahan beracun apabila digunakan dalam makanan, sehingga penggunaannya dilarang sebagai pengawet makanan. Meskipun boraks telah dilarang penggunaannya sebagai bahan pengawet makanan, namun masih terdapat produsen yang menggunakan bahan pengawet tersebut untuk mengawetkan makanan. Boraks memiliki sifat toksik bagi sel, beresiko terhadap kesehatan manusia yang mengonsumsi makanan mengandung boraks(See et al., 2010). Para produsen masih banyak yang menggunakan boraks secara sengaja ataupun tidak sengaja untuk pembuatan mie, lontong, kerupuk, bakso dan panganan lainnya. Pada dasarnya boraks berfungsi sebagai solder, bahan pembersih, pengawet kayu, antiseptik, dan pengontrol kecoa dan lalat(Sugiyatmi, 2006)tidak berfungsi sebagai pengawet makanan. Keseringan mengkonsumsi makanan yang mengandung boraks dapat menyebabkan gangguan otak, hati, lemak dan ginjal, sedangkan konsumsi boraks dalam jumlah yang relatif tinggi dapat menybabkan demam, anuria (tidak terbentuknya urin), koma, apatis, sianosis, tekanan darah turun, kerusakan ginjal dan kematian.Dosis boraks yang sangat tinggi 
masuk kedalam tubuh makhluk hidup dapat mengakibatkan kematian mendadak(Kabu et al., 2015)

Bahan tambahan pangan yang paling sering digunakan pedagang "nakal" karena mudah didapatkan dan diaplikasikan adalah Boraks dengan nama kimia sodium tetraborat deksahidrat $\left(\mathrm{Na}_{2} \mathrm{~B}_{4} \mathrm{O}_{7} \mathrm{10H}_{2} \mathrm{O}\right)$. Ciri-ciri Boraks biasanya berbentuk kristal putih, tidak berbau, dan mudah larut dalam air (tidak dapat larut dalam alkohol). Boraks merupakan garam natrium yang semestinya dipergunakan di industri non pangan, seperti industri keramik, pengawet kayu, gelas, dan kertas. Bahan tambahan pangan lainnya yang juga dapat bersifat sebagai pengawet adalah Formalin, dengan nama kimia Formaldehida $\left(\mathrm{CH}_{2} \mathrm{O}\right)$, yang berwujud cair. Bahan tambahan pangan (bahan pengawet) ini seringkali digunakan oleh para pedagang "nakal" sebab harganya yang murah dan penggunaannya yang relatif lebih sedikit dibanding bahan pengawet yang memang disarankan untuk bahan makanan.

Permasalahan yang dihadapi oleh masyarakat yaitu terdapatnya pedagang yang masih menggunakan bahan pengawet seperti boraks dan formalin yang digunakan sebagai pengawet makanan. Namun dengan beredarnya panganan yang mengandung boraks dan formalin, namun masyarakat masih belum memiliki pemahaman mengenai karakteristik bahan makanan yang mengandung boraks dan formalin. Selain itu, masyarakat juga belum memiliki pemahaman mengenai bahaya dari penggunaan boraks dan formalin terhadap kesehatan masyarakat. Masyarakat juga belum memiliki pengetahuan dan keterampilan untuk mengidentifikasi boraks dan formalin dalam makanan dengan menggunakan metode sederhana. Oleh sebab itu, melalui kegiatan pengabdian kepada masyarakat ini masyarakat diberikan pengetahuan dan keterampilan mengidentifikasi boraks dan formalin dengan menggunakan kertas tumerik dan kertas bunga kembang sepatu yang dapat diperoleh dengan mudah di lingkungan. Metode identifikasi ini dengan mudah dapat diterapkan oleh masyarakat di rumah dengan menggunakan kunyit dan bunga kembang sepatu.

\section{METODE PELAKSANAAN}

Kegiatan ini dilaksanakan pada bulan Juli hingga Oktober 2019 pada Ibu PKK di Kelurahan Tanjung Ayun Sakti, Tanjungpinang-Kepulauan Riau. Alat dan bahan yang digunakan dalam kegiatan PKM ini yaitu sampel bakso, pempek, otak-otak, tahu, tempe, mie, terasi, ekstrak kunyit, ekstrak kembang sepatu, kertas indikator tumerik dan bunga kembang sepatu. Metode yang digunakan dalam kegiatan ini yaitu 1) survey, 2) tahap preparasi atau persiapan ekstrak kunyit dan bunga kembang sepatu dan pembuatan kertas indikator, 3) tahap penyuluhan, dan 4) tahap pelatihan.

Pada tahap survey dilakukan pengumpulan informasi permasalahan yang dihadapi mitra serta pengumpulan sampel makanan laut yang dijual. Pada tahap preparasi dilakukan pembuatan ekstrak kunyit dan bunga kembang sepatu serta kertas indikator yaitu kertas tumerik dan bunga kembang sepatu. Selanjutnya mengidentifikasi sampel makanan dengan menggunakan kertas indikator ataupun ekstrak kunyit dan bunga kembang sepatu secara kualitatif dengan simple methods. 
Tahapan selanjutnya yaitu tahap penyuluhan yang akan memberikan informasi dan pengetahuan mengenai bahaya bahan pengawet seperti boraks dan formalin bagi kesehatan. Tahapan berikutnya yaitu tahapan pelatihan. Masyarakat dilatih untuk mengidentifikasi dalam membuat ekstrak kunyit dan bunga kembang sepatu serta kertas indikator tumerik dan kembang sepatu, dan mengidentifikasi sampel makanan mengandung boraks dan formalin. Untuk mengetahui ketercapaian pelaksanaan kegiatan ini kepada masyarakat diberikan angket respon masyarakat terhadap pelaksanaan kegiatan.

\section{HASIL DAN PEMBAHASAN}

Kegiatan pengabdian ini dilakukan dalam beberapa tahapan yaitu tahap survey, persiapan/preparasi, penyuluhan dan pelatihan. Pada tahap persiapan dilakukan penyediaan ekstrak kunyit dan bunga kembang sepatu serta kertas indikator tumerik dan bunga kembang sepatu. Hasil yang diperoleh dari kegiatan pengabdian kepada masyarakat yaitu:

1. Tahap survey

Tahap survey dilakukan untuk melihat kondisi masyarakat terkait pemahaman masyarakat mengenai karakteristik dan bahaya boraks dan formalin bagi kesehatan. Dalam tahapan ini dilakukan untuk mengumpulkan informasi permasalahan apa yang dihadapi oleh masyarakat terkait penggunaan boraks dan formalin dalam produk pangan. Selain itu, dalam tahapan ini juga dilakukan observasi lapangan di beberapa titik lokasi penjual jajanan di daerah Pamedan, Bintan Centre, Batu X, Tepi Laut, Batu 11, dan Ganet. Kemudian dari lokasi ini dikumpulkan sampel uji yang akan di uji secara kualitatif di laboratorium.

2. Tahap Persiapan/ Pembuatan Kertas Indikator Tumerik dan Bunga Kembang Sepatu

Pada tahap ini dilakukan persiapan ekstrak kunyit yang berwarna kuning dan ekstrak kembang sepatu berwarna merah-ungu. Selanjutnya kertas saring Whatmann direndam di dalam ekstrak tersebut dan dihasilkan kertas indikator tumerik dan bunga kembang sepatu dan dapat dilihat pada Gambar 1.

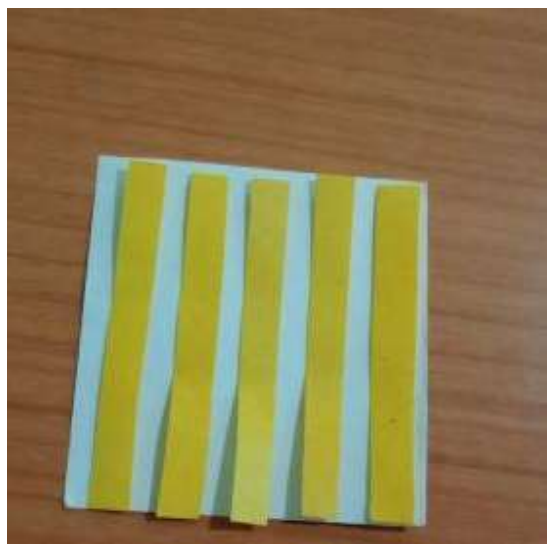

(a)

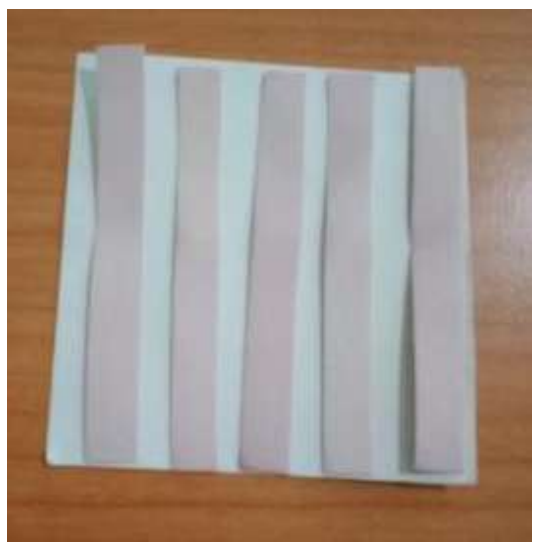

(b)

Gambar 1. Kertas indikator (a) Tumerik (kunyit) dan (b) Bunga Kembang Sepatu

Penelitian mengenai pengujian boraks secara kualitatif telah dilaksanakan oleh Istiqomah et al., 2016 yang dilakukan uji terhadap bakso dengan menggunakan kertas 
turmerik dan dari 160 sampel yang diuj, memberikan hasil negatif terhadap boraks. Oleh sebab itu, untuk memberikan pelatihan kepada masyarakat digunakan metode sederhana yang dapat diterapkan oleh masyarakat dirumah dengan menggunakan kertas turmerik. Selanjutnya, kertas indikator ini digunakan untuk mengidentifikasi boraks dan formalin dalam bentuk boraks dan formalin murni untuk mengujicoba kertas yang telah dihasilkan. Untuk larutan boraks dibuat dari garam natrium borat yang dilarutkan dalam air dan kemudian diuji dengan menggunakan kertas indikator Tumerik dan memberikan perubahan warna pada kertas yaitu dari warna kuning berubah menjadi warna merah-kecoklatan. Hal ini disebabkan oleh ekstrak kunyit yang mengandung senyawa kurkumin dapat menguraikan ikatan dari senyawa boraks natrium borat $\left(\mathrm{Na}_{2} . \mathrm{B}_{4} \mathrm{O}_{7} .10 \mathrm{H}_{2} \mathrm{O}\right)$ menjadi asam borat $\left(\mathrm{H}_{3} \mathrm{BO}_{3}\right)$ dan mengikat senyawa kompleks berwarna boron cyano kurkumin sehingga pada saat sampel senyawa booraks ditetesi dengan ekstrak kunyit/kertas Tumerik maka dapat menyebabkan perubahan warna dari kuning menjadi merah-kecoklatan(Halim et al., 2012). Untuk memperoleh hasil positif mengandung boraks maka terjadi reaksi antara boraks dan kurkumin yang membentuk senyawa rosocyanine yang menyebabkan warna oranye hingga merah pada produk pangan yang mengandung boraks (Grynkliewicz et al., 2012).

Selanjutnya untuk menguji boraks juga digunakan kertas indikator bunga kembang sepatu. Kertas indikator bunga kembang sepatu dibuat dengan proses maserasi atau perendaman bunga kembang sepatu yang telah dipotong kecil-kecil di dalam alkohol 70\% selama 1 jam. Hasil proses maserasi ini digunakan untuk merendam kertas saring Whatmann selama 24 jam dan kemudian dikeringkan. Perubahan yang terjadi jika terdapat boraks maka mengalami perubahan warna dari warna merah muda menjadi warna hijau. Hasil ujicoba kertas indikator pada larutan murni boraks dapat dilihat pada Gambar 2.

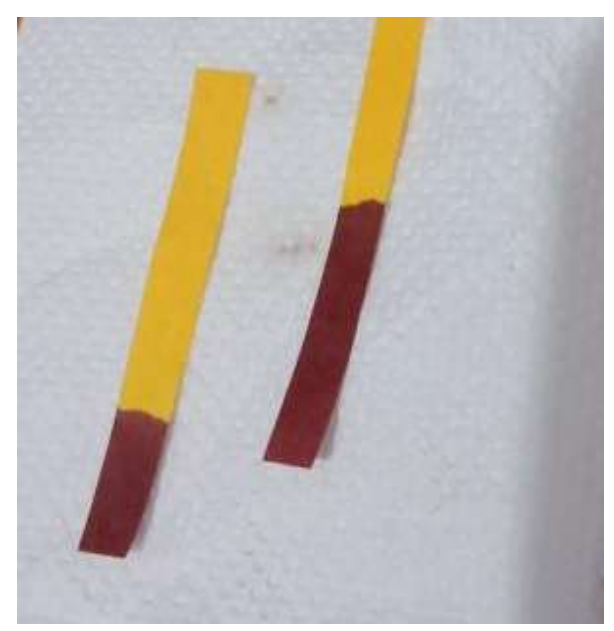

(a)

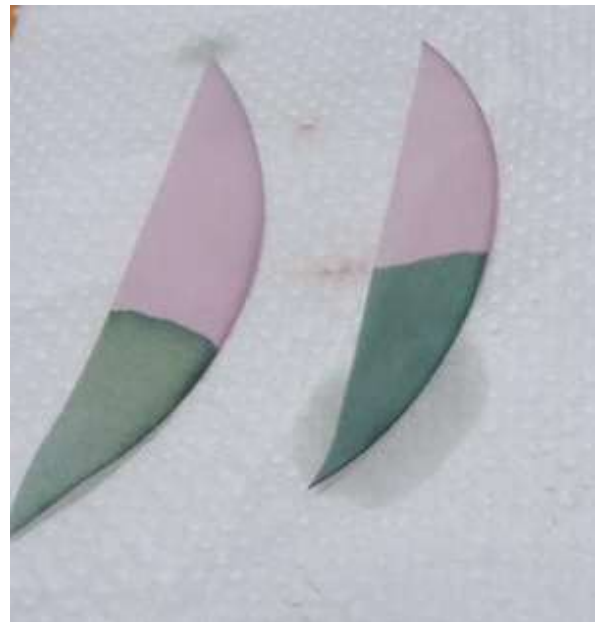

(b)

Gambar 2. Hasil uji larutan murni boraks (a) menggunakan kertas Tumerik memberikan perubahan dari kuning menjadi merah-kecoklatan; (b) kertas bunga kembang sepatu memberikan perubahan dari warna merah muda menjadi hijau

Selanjutnya dilakukan pengujian terhadap beberapa sampel makanan yang dijual di lingkungan masyarakat seperti bakso cilok, pempek, dan otak-otak. Sampel bakso 
cilok dikumpulkan dari daerah Pamedan, Bintan Centre, dan Batu X (dekat SMPN 7). Untuk sampel pempek dikumpulkan dari daerah Tepi Laut, Batu 11, dan Ganet dan untuk sampel otak-otak dikumpulkan dari daerah Tepi Laut. Untuk hasil yang diperoleh dari identifikasi bahan makanan dengan menggunakan kertas indikator dapat dilihat pada Tabel 1.

Tabel 1. Hasil Uji Coba Sampel Makanan dengan Kertas Indikator

\begin{tabular}{|c|c|c|c|c|}
\hline Uji & Sampel & $\begin{array}{c}\text { Warna } \\
\text { Kertas } \\
\text { sebelum }\end{array}$ & $\begin{array}{c}\text { Warna } \\
\text { Kertas } \\
\text { Sesudah }\end{array}$ & Kesimpulan \\
\hline \multirow{7}{*}{ Boraks } & Bakso I & Kuning & Kuning & Negatif \\
\hline & Bakso II & Kuning & Kuning & Negatif \\
\hline & Bakso III & Kuning & Kuning & Negatif \\
\hline & Pempek I & Kuning & Kuning & Negatif \\
\hline & Pempek II & Kuning & Kuning & Negatif \\
\hline & Pempek III & Kuning & Kuning & Negatif \\
\hline & Otak-otak & Kuning & Kuning & Negatif \\
\hline \multirow[t]{7}{*}{ Formalin } & Bakso I & Merah Muda & Merah Muda & Negatif \\
\hline & Bakso II & Merah Muda & Merah Muda & Negatif \\
\hline & Bakso III & Merah Muda & $\begin{array}{l}\text { Cincin ungu } \\
\text { gelap dasar } \\
\text { putih }\end{array}$ & Positif \\
\hline & Pempek I & Merah Muda & $\begin{array}{l}\text { Cincin ungu } \\
\text { gelap dasar } \\
\text { putih }\end{array}$ & Positif \\
\hline & Pempek II & Merah Muda & $\begin{array}{l}\text { Cincin ungu } \\
\text { gelap dasar } \\
\text { putih }\end{array}$ & Positif \\
\hline & Pempek III & Merah Muda & $\begin{array}{l}\text { Cincin ungu } \\
\text { gelap dasar } \\
\text { putih }\end{array}$ & Positif \\
\hline & Otak-otak & Merah Muda & Merah Muda & Negatif \\
\hline
\end{tabular}

Pengujian boraks dalam makanan dengan menggunakan kertas tumerik juga telah dilakukan oleh Rz dan Yandra (2017) dengan melakukan kegiatan pengabdian kepada masyarakat untuk mengidentifikasi boraks dalam makanan dan kegiatan ini dapat meningkatkan pemahaman masyarakat tebing tinggi Okura tentang bahaya boraks bagi kesehatan dan dapat mengetahui ciri-ciri makanan yang mengandung boraks.

3. Tahap Sosialisasi

Kegiatan sosialisasi ini dilaksanakan di Kelurahan Tanjung Ayun Sakti, Tanjungpinang dan diikuti oleh 25 peserta yang merupakan komunitas Ibu PKK yang berdomisili di Kelurahan tersebut. Kegiatan ini dilakukan dalam rangka memberikan edukasi dan informasi kepada masyarakat mengenai Bahan Tambahan Pangan (BTP), jenis BTP, bahan pengawet boraks dan formalin, bahaya boraks dan formalin terhadap kesehatan, karakteristik bahan makanan yang mengandung boraks dan formalin, serta pengolahan makanan tidak menggunakan bahan pengawet berbahaya boraks dan formalin. Kegiatan sosialisasi ini dilaksanakan menggunakan metode ceramah, diskusi dan tanya jawab. Kegiatan sosialisasi ini berjalan dengan kondusif dan para peserta antusias dalam mendengarkan pemaparan materi yang disampaikan. Hal ini ditandai dengan banyaknya pertanyaan yang disampaikan oleh masyarakat terkait dengan bahan 
makanan yang mengandung boraks dan formalin yang terdapat pada beberapa makanan yang dipasarkan di pasaran.

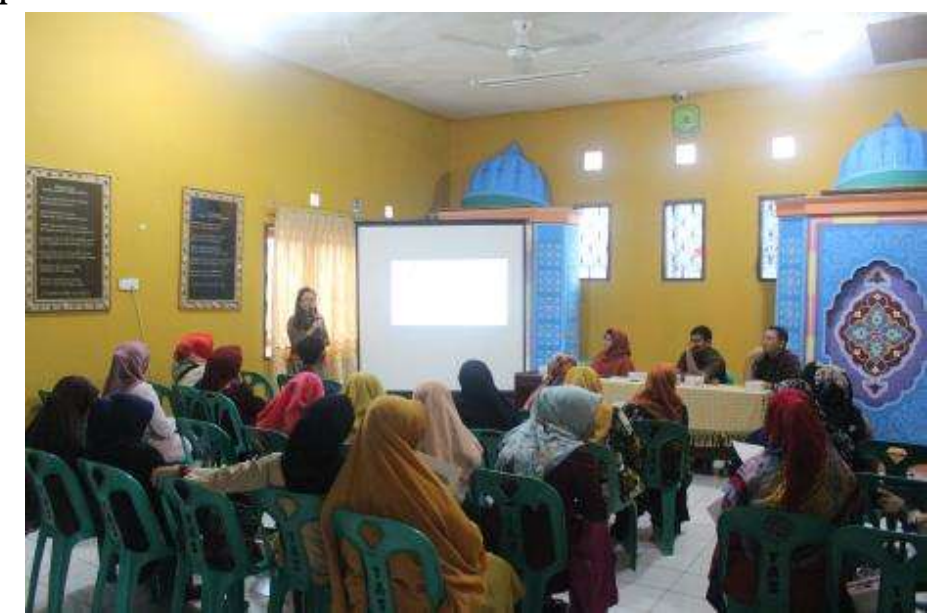

Gambar 3. Penyampaian Materi kepada Masyarakat oleh Pemateri

Hasil yang diperoleh melalui kegiatan sosialisasi yaitu dapat meningkatkan wawasan dan pengetahuan masyarakat mengenai bahaya penggunaan boraks dan formalin terhadap kesehatan, serta karakteristik bahan makanan yang mengandung boraks dan formalin.

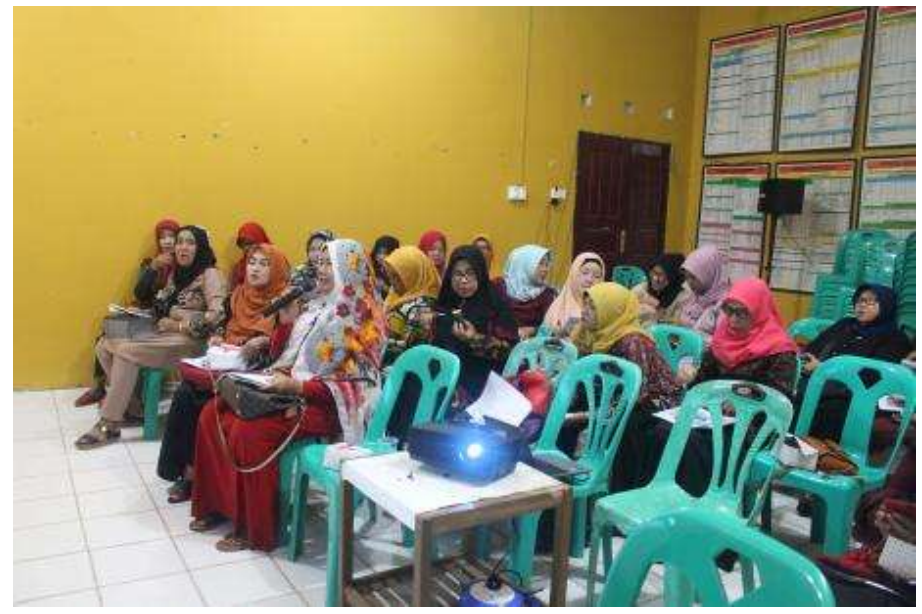

Gambar 4. Suasana Diskusi dan Tanya Jawab dengan Peserta

\section{Tahap Pelatihan}

Kegiatan pelatihan ini bertujuan untuk memberikan pelatihan keterampilan kepada masyarakat untuk mengidentifikasi boraks dan formalin di dalam bahan makanan yaitu bakso, tahu, tempe, pempek, mie basah, terasi yang dipasarkan di lingkungan masyarakat. Metode yang digunakan untuk mengidentifikasi boraks dan formalin yaitu menggunakan metode sederhana atau simple methods yaitu menggunakan kertas indikator Tumerik dan bunga kembang sepatu yang dapat diperoleh masyarakat dari alam untuk pembuatan ekstraknya yaitu dari kunyit dan bunga kembang sepatu. Tahap pelatihan dilakukan dengan memberikan cara memberikan:

a. pelatihan pembuatan ekstrak kunyit dan bunga kembang sepatu. 
b. pembuatan kertas indikator Tumerik dan bunga kembang sepatu dan kertas saring Whattman no.41 yang mengadsorp ekstrak kunyit dan bunga kembang sepatu.

c. metode pengidentifikasian boraks dan formalin dengan menggunakan kertas Tumerik yang memberikan perubahan warna dari kuning menjadi merahkecoklatan pada sampel makanan yang mengandung boraks. Kertas indikator bunga kembang sepatu memberikan perubahan warna menjadi cincin ungu pada kertas indikator untuk sampel yang mengandung formalin

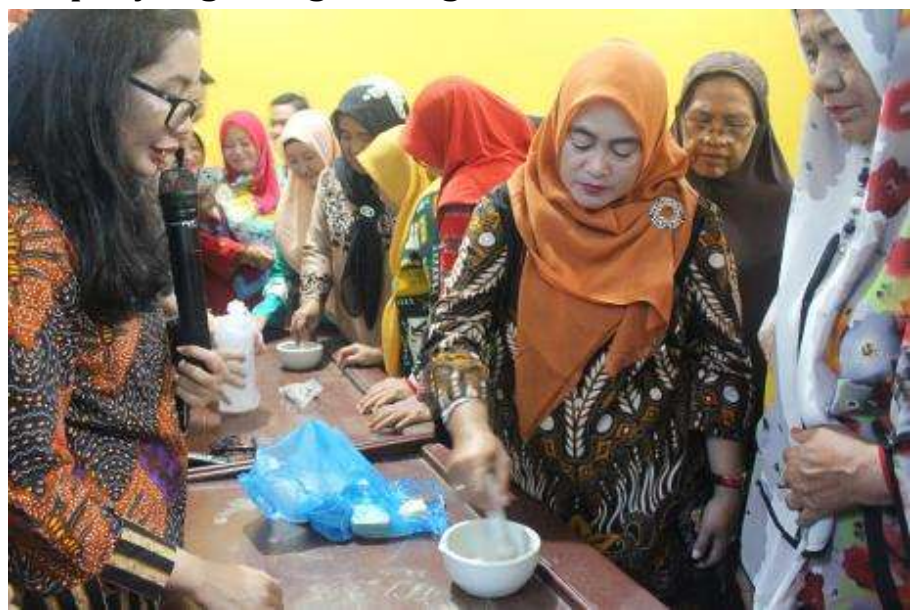

Gambar 5. Masyarakat mengidentifikasi boraks dan formalin dengan menggunakan simple methods dengan kertas indikator Tumerik dan bunga kembang sepatu

Adapun hasil identifikasi yang diperoleh dari kegiatan pelatihan ini berdasarkan kualitas atau tekstur bahan makanan yang diujicoba pada saat pelatihan dapat dilihat pada Tabel 2.

Tabel 2. Hasil Karakteristik Sampel Bahan Makanan yang Diujicoba

\begin{tabular}{|c|c|}
\hline Uji Boraks & Uji Formalin \\
\hline $\begin{array}{l}\text { 1. Tidak mengalami perubahan warna dari } \\
\text { kuning menjadi merah kecoklatan ketika } \\
\text { diuji dengan kertas Tumerik }\end{array}$ & $\begin{array}{l}\text { Tidak mengalami perubahan warna dari } \\
\text { merah muda menjadi ungu ketika diuji } \\
\text { dengan menggunakan kertas kembang } \\
\text { sepatu }\end{array}$ \\
\hline $\begin{array}{l}\text { 4. Memiliki aroma yang tidak menyengat dan } \\
\text { memiliki aroma ikan, tepung. }\end{array}$ & Tidak beraroma menyengat formalin \\
\hline $\begin{array}{l}\text { 3. Sampel bahan makanan rusak pada suhu } \\
\text { kamar pada suhu kamar setelah } 3 \text { hari }\end{array}$ & $\begin{array}{l}\text { Sampel bahan makanan rusak pada } \\
\text { suhu kamar setelah } 3 \text { hari }\end{array}$ \\
\hline $\begin{array}{l}\text { 4. Memiliki warna yang tidak mencolok/ } \\
\text { mengkilat }\end{array}$ & $\begin{array}{l}\text { 4. Tidak berwarna putih mengkilat pada } \\
\text { bakso dan memiliki }\end{array}$ \\
\hline
\end{tabular}

Dalam kegiatan pelatihan, digunakan beberapa sampel makanan untuk diidentifikasi keberadaan boraks dan formalin. Sampel bahan makanan yang digunakan yaitu bakso ikan, tahu, tempe, mie basah, terasi dan pempek. Sampel dihaluskan dengan menggunakan akuades untuk menghasilkan ekstrak sampel dan diuji dengan menggunakan kertas indikator Tumerik yang memberikan hasil positif terjadi perubahan warna dari kuning menjadi merah-kecoklatan. Untuk pengujian formalin digunakan kertas indikator bunga kembang sepatu yang memberikan hasil positif yaitu terjadi perubahan warna menjadi ungu muda. Hasil identifikasi sampel bahan makanan dengan kertas indikator Tumerik dan bunga kembang sepatu pada beberapa sampel dapat dilihat pada Tabel 3.

Tabel 3. Hasil Uji Warna Sampel Bahan Makanan dengan Kertas Tumerik dan Bunga Kembang Sepatu 


\begin{tabular}{|c|c|c|c|c|c|c|}
\hline \multirow{2}{*}{$\begin{array}{c}\text { Kode } \\
\text { Sampel }\end{array}$} & \multicolumn{3}{|c|}{ Kertas Tumerik } & \multicolumn{3}{|c|}{ Kertas Bunga Kembang Sepatu } \\
\hline & $\begin{array}{c}\text { Warna } \\
\text { sebelum }\end{array}$ & $\begin{array}{l}\text { Warna } \\
\text { Sesudah }\end{array}$ & Hasil & $\begin{array}{c}\text { Warna } \\
\text { sebelum }\end{array}$ & Warna sesudah & Hasil \\
\hline Sampel 1 & Kuning & Kuning & Negatif $(-)$ & Merah muda & Merah Muda & Negatif $(-)$ \\
\hline Sampel 2 & Kuning & $\begin{array}{l}\text { Merah- } \\
\text { coklat }\end{array}$ & Positif $(+)$ & Merah muda & Merah Muda & Negatif $(-)$ \\
\hline Sampel 3 & Kuning & Kuning & Negatif (-) & Merah muda & $\begin{array}{l}\text { Cincin ungu gelap } \\
\text { dasar putih }\end{array}$ & Positif (+) \\
\hline Sampel 4 & Kuning & $\begin{array}{l}\text { Merah- } \\
\text { coklat }\end{array}$ & Positif (+) & Merah muda & Merah Muda & Negatif $(-)$ \\
\hline Sampel 5 & Kuning & Kuning & Negatif $(-)$ & Merah Muda & Merah Muda & Negatif $(-)$ \\
\hline Sampel 6 & Kuning & Kuning & Negatif $(-)$ & Merah Muda & Merah Muda & Negatif $(-)$ \\
\hline Sampel 7 & Kuning & Kuning & Negatif $(-)$ & Merah Muda & Merah Muda & Negatif $(-)$ \\
\hline Sampel 8 & Kuning & Kuning & Negatif (-) & Merah Muda & $\begin{array}{l}\text { Cincin ungu gelap } \\
\text { dasar putih }\end{array}$ & Positif $(+)$ \\
\hline
\end{tabular}

\section{Keterangan:}

$\begin{array}{llll}\text { Sampel 1 } & \text { : Bakso Ikan 1 } & \text { Sampel 5 } & \text { : Tahu } \\ \text { Sampel 2 } & \text { : Bakso Ikan 2 } & \text { Sampel 6 } & \text { : Tempe } \\ \text { Sampel 3 } & \text { : Bakso Udang } & \text { Sampel 7 } & \text { : Terasi } \\ \text { Sampel 4 } & \text { : Mie Basah } & \text { Sampel 8 } & \text { : Pempek }\end{array}$

Melalui kegiatan pelatihan secara kualitatif, masyarakat dapat melakukan identifikasi bahan makanan yang dipasarkan apakah mengandung boraks atau formalin sehingga lebih aman untuk dikonsumsi.

Untuk pengujian boraks dalam mie juga pernah dilakukan oleh Widelia et al (2018) yang telah melakukan identifikasi kandungan boraks pada mi basah di pasar tradisional bengkulu yang diperoleh data bahwa dari 33 sampel mi basah yang dijual di pasar masih terdapat 22 sampel $(66,66 \%)$ mengandung boraks. Selain mi, panganan khas dari Provinsi Kepulauan Riau khususnya Tanjungpinang adalah otak-otak. Dari hasil pengujian awal diperoleh hasil bahwa sampel uji memberikan hasil negatif terhadap boraks dan formalin. Namun penelitian sebelumnya telah dilakukan pengujian sampel otak-otak di Tanjungpinang dan diperoleh hasil bahwa masih terdapat 1 sampel yang mengandung boraks dan formalin (Doliyanto, 2013). Selain itu, program pengabdian kepada masyarakat juga telah dilakukan oleh Nancy (2015) dimana memberikan sosialisasi makanan sehat tanpa formalin di kelurahan Kp.Bugis dan Kelurahan Dompak sehingga diperoleh hasil bahwa melalui kegiatan tersebut sekitar 75\% peserta telah memahami ciri-ciri makanan yang berformalin.

5. Tahap Evaluasi

Tahap evaluasi ini dilakukan untuk mengetahui kepuasan masyarakat terhadap kegiatan kepada masyarakat yang telah dilakukan. Untuk mengetahui kepuasan masyarakat diberikan instrumen angket kepuasan menggunakan skala Likert dengan pilihan jawaban 1-5 ( 1 =tidak puas; 2 =kurang puas; 3 =cukup puas; 4=puas; $5=$ =sangat puas). Angket ini diberikan kepada 25 orang jumlah peserta kegiatan Pengabdian kepada Masyarakat. Adapun hasil yang diperoleh dari evaluasi ini dapat dilihat pada Tabel 4.

Tabel 4. Tingkat Kepuasan Masyarakat terhadap kegiatan PkM di Kelurahan Tanjung Ayun Sakti

\begin{tabular}{|c|l|c|c|c|c|}
\hline No & \multicolumn{2}{|c|}{ Uraian } & Jumlah & Rata-rata & Keterangan \\
\hline 1 & $\begin{array}{l}\text { Program Pengabdian kepada Masyarakat (PkM) } \\
\text { dilaksanakan sesuai dengan kebutuhan masyarakat }\end{array}$ & 116 & 4,64 & Sangat Puas \\
\hline
\end{tabular}




\begin{tabular}{|c|c|c|c|c|}
\hline 2 & $\begin{array}{l}\text { Materi yang disampaikan dalam kegiatan PkM sangat } \\
\text { dibutuhkan oleh masyarakat }\end{array}$ & 103 & 4,12 & Puas \\
\hline 3 & $\begin{array}{l}\text { Keterkaitan hubungan antara materi yang disajikan } \\
\text { sesuai dengan kebutuhan masyarakat }\end{array}$ & 104 & 4,16 & Puas \\
\hline 4 & Kejelasan materi yang disampaikan Tim Pengabdian & 110 & 4,4 & Puas \\
\hline 5 & $\begin{array}{l}\text { Program PkM telah memberikan bekal kepada } \\
\text { masyarakat berupa kemampuan berpikir ataupun } \\
\text { keterampilan mengidentifikasi boraks dan formalin } \\
\text { dengan kertas Tumerik dan kertas bunga kembang } \\
\text { sepatu }\end{array}$ & 115 & 4,6 & Sangat Puas \\
\hline 6 & $\begin{array}{l}\text { Pelaksanaan program PkM dalam upaya pemberian } \\
\text { edukasi kepada masyarakat telah mampu meningkatkan } \\
\text { pengetahuan dan wawasan masyarakat mengenai ciri- } \\
\text { ciri bahan makanan yang mengandung boraks dan } \\
\text { formalin, bahaya boraks dan formalin bagi kesehatan }\end{array}$ & 119 & 4,76 & Sangat Puas \\
\hline 7 & $\begin{array}{l}\text { Pelaksanaan program PkM dapat meningkatkan } \\
\text { keterampilan masyarakat untuk mengidentifikasi boraks } \\
\text { dan formalin dalam makanan dengan menggunakan } \\
\text { metode sederhana dengan menggunakan kertas tumerik } \\
\text { dan bunga kembang sepatu. }\end{array}$ & 118 & 4,72 & Sangat Puas \\
\hline 8 & $\begin{array}{l}\text { Melalui program PkM ini masyarakat telah memperoleh } \\
\text { manfaat/terbantukan dalam penyelesaian masalahnya } \\
\text { dari pelaksanaan PkM }\end{array}$ & 114 & 4,56 & Sangat Puas \\
\hline
\end{tabular}

Berdasarkan data tingkat kepuasan masyarakat, maka dapat disimpulkan bahwa masyarakat sangat puas dengan rata-rata kepuasan 4,5-4,7 dengan kegiatan pengabdian dengan menggunakan metode sosialisasi dan pelatihan sehingga memberikan nilai optimal pengetahuan dan keterampilan yang sangat baik kepada masyarakat. Dalam pelaksanaan kegiatan PkM masyarakat juga menunjukkan sikap antusias terhadap penyampaian materi dan pelatihan.

\section{SIMPULAN}

Berdasarkan kegiatan Pengabdian kepada Masyarakat yang telah dilaksanakan di Kelurahan Tanjung Ayun Sakti, maka dapat disimpulkan: 1) kegiatan sosialisasi ini telah dapat meningkatkan pemahaman masyarakat mengenai ciri-ciri makanan yang mengandung boraks dan formalin, 2) kegiatan pelatihan ini dapat meningkatkan keterampilan masyarakat untuk dapat mengidentifikasi boraks dan fornalin yang terdapat dalam bahan makanan dengan menggunakan kertas Tumerik dan bunga kembang sepatu, 3) dari 15 sampel uji, terdapat 2 sampel (13,3\%) yang mengandung boraks dan 6 sampel (40\%) yang mengandung formalin.

\section{SARAN}

Masih diperlukannya penelitian lebih lanjut untuk menganalisis kadar boraks dan formalin yang terdapat dalam sampel makanan. Selain itu, diperlukan penelitian lanjutan untuk menemukan indikator alami yang dapat digunakan sebagai indikator alami untuk mengidentifikasi bahan pengawet berbahaya seperti boraks dan formalin.

\section{UCAPAN TERIMA KASIH}

Penulis mengucapkan terimakasih kepada Lembaga Penelitian Pengabdian Masyarakat dan Penjaminan Mutu (LP3M) Universitas Maritim Raja Ali Haji yang telah memberikan 
dukungan dana pada Tahun 2019 serta Kelurahan Tanjung Ayun Sakti Tanjungpinang yang merupakan mitra dalam kegiatan Pengabdian Kepada Masyarakat.

\section{DAFTAR RUJUKAN}

Doliyanto. 2013. Hygiene Sanitasi Makanan dan Pemeriksaan Formalin serta Boraks pada Makanan Jajanan (Otak-Otak) di Kota Tanjungpinang Tahun 2013. Skripsi. Universitas Sumatera Utara.

Grynkliewicz,G., Slifiski, P. (2012) Curcumin and Curcuminoid in QUest for Medicinal Status. ACTA ABP, 59. 205.

Halim, A. A., Fattah, A., Bakar, A., Ahmad, M., Megat, K., Zakaria, H., Teknologi, U., \& Pahang, M. (2012). Boron Removal from Aqueous Solutions Using Curcumin-Aided Electrocoagulation Environmental Health Programme, Faculty of Allied Health Sciences ,. 11(5), 583-588.

Istiqomah, S, Sudarwanto,M.B.,Sudarnika,E. (2016). Penambahan Boraks dalam Bakso dan Faktor Pendorong Penggunaannya Bagi Pedagang Bakso di Kota Bengkulu. Jurnal Sains Veteriner, 32(1), 1-8.

Kabu, M., Tosun, M., Elitok, B., \& Akosman, M. S. (2015). Histological Evaluation of the Effects of Borax Obtained from Various Sources in Different Rat Organs. International Journal of Morphology, 33(1), 255-261.

Peraturan Menteri Kesehatan Republik Indonesia Nomor 033 Tahun 2012 tentang Bahan Tambahan Pangan. Jakarta: Departemen Kesehatan RI. [Internet]. [diunduh 2017 Oktober 3]

Rz, I,R., dan Yandra, A. (2017). Preventif Aproach: Bahaya Borak dan Cara Mengidentifikasi Makanan yang Mengandung Borak. Jurnal Pengabdian Kepada Masyarakat,Dinamisia. 1(1). 23-28.

Sugiyatmi,S. (2006). Analisis Faktor-Faktor Risiko Pencemaran Bahan Toksik Boraks dan Pencemaran Bahan Toksis Boraks dan Pewarna Pada Makanan Jajanan Tradisional yang Dijual di Pasar-Pasar Kota Semarang Tahun 2006. Tesis. Universitas Diponogoro, Semarang.

See, A. S., Salleh, A. B., Bakar, F. A., Yusof, N. A., Abdulamir, A. S., \& Heng, L. Y. (2010). Risk and health effect of boric acid. American Journal of Applied Sciences, 7(5), 620-627.

Widelia, P., Farizal, J., dan Narti, M. (2018). Identifikasi Kandungan Boraks pada Mi Basah di Pasar Tradisional Kota Bengkulu. Journal of Nursing and Public Health. 6(1). 58-62

Willian, N. (2015). Optimalisasi Peran Serta Masyarakat dalam Peningkatan Kesadaran Peduli Makanan Sehat Tanpa Formalin Pada Jajanan Sekolah. Artikel Publikasi. Universitas Maritim Raja Ali Haji 
68 J-Abdipamas, Vol. 4, No. 1 April, 2020 